\title{
Legen som sakkyndig
}

Leger som tar på seg oppgaver som sakkyndig i medisinske spørsmål, må klarlegge sin rolle overfor pasienten.

\section{Trond Markestad}

trond.markestad@helse-bergen.no

Rådet for legeetikk

Den norske legeforening

Postboks 1152 Sentrum

0107 Oslo

Fra pasienter får Rådet for legeetikk ofte klager på leger som har fungert som sakkyndig for forsikringsselskap, NAV og andre instanser. Klagen skyldes av og til at pasienten er misfornøyd med legens medisinske vurdering. Slike klager tar rådet ikke stilling til, jf. Reglement for Rådet for legeetikk $\S 2$, som sier at «Rådet behandler ikke saker som gjelder den faglige delen av medisinsk virksomhet...».

Ofte gjelder imidlertid klagen legens måte å opptre på. Slike klager har gjerne som undertone at pasienten er misfornøyd med den medisinske vurderingen, og rådet tror at mange av disse klagene ville ha vært unngått dersom legen hadde vært tydeligere overfor pasienten om sin rolle som sakkyndig. Følgende klage illustrerer en slik situasjon.

\section{Klagen}

Innklagede lege var engasjert som sakkyndig av et forsikringsselskap for å vurdere helsetilstanden til klager som følge av en ulykke. Klager opplevde legen som arrogant, irritert og mistroisk til det hun fortalte om sin helsetilstand. Klager skrev at legen ikke hilste på henne, at han snakket nedsettende om psykologer og underkjente dia- gnosen posttraumatisk stressyndrom, fastsatt av hennes psykolog, og at han var lite interessert i klagers psykiske helse og hvordan det hadde påvirket livet hennes. Klager viste også til at legen i sin vurdering av hennes helse ikke hadde tatt hensyn til relevante undersøkelser utført av andre faginstanser. Innklagede leges konklusjon var at klagers helse ikke var forverret sammenliknet med hvordan han vurderte den noen år tidligere. Dette var klager uenig i.

Innklagede lege skrev i sin redegørelse at han ikke kjenner seg igjen i det som hevdes. Han hevdet at han ikke var irritert eller mente å være arrogant eller mistroisk. Han redegjorde for hva som er en sakkyndigs oppgave og spesielle mandat. Som sakkyndig skulle han vurdere klagers hode- og nakkeskade. Forklaringen på at klager opplevde ham som generelt negativ, og særlig i forhold til psykologer, mente han kunne bero på en misforståelse, fordi hennes psykiske helse ikke var en del av hans mandat, og fordi han informerte henne om at diagnosen posttraumatisk stressyndrom, ifølge regelverket, må stilles av psykiater når det er spørsmål om menerstatning. Avslutningsvis sa han seg lei for at klager opplevde ham som negativ.

\section{Rådets uttalelse}

Rådet mottar ikke sjelden klage på leger som fungerer som sakkyndig overfor forsikringsselskap eller offentlige instanser som NAV eller rettsvesenet. Ofte skyldes det at klager ikke føler seg godt ivaretatt som pasient, men opplever situasjonen som ydmykende og sakkyndig lege som avmålt, arrogant, mistenksom og på parti med oppdragsgiveren. Følelsen forsterkes gjerne av at den sakkyndige legen er oppnevnt av forsikringsselskapet eller tjenesteyter uten at pasienten har hatt noen reell innflytelse på oppnevnelsen.

I en sak som denne foreligger det ikke noe ordinært lege-pasient-forhold. Legens oppgave er å utrede og vurdere en pasients rettigheter ut fra et gitt mandat og regelverk. Det er forståelig at kommunikasjonen vil kunne bære preg av det og lett kan bli særlig krevende. Legens formelle rolle, det at legen gjerne er ukjent for pasienten, og at pasienten ofte er i en spesielt sårbar situasjon, er momenter som kan skape grunnlag for misforståelser og negativ opplevelse. De spesielle forholdene knyttet til en sakkyndig vurdering fritar imidlertid ikke legen fra å ivareta de samme krav om å vise «barmhjertighet, omsorg og respekt.» for pasienten som i en mer ordinær konsultasjon, jfr. Etiske regler for leger, kap I, § 2.

Rådet merker seg at partene har opplevd møtet forskjellig og kan ikke ta konkret stilling i saken. En pasients tilbakemelding er imidlertid alltid en viktig kilde til refleksjon over egen måte å opptre på, og rådet konstaterer at innklagede lege sier seg lei for at han ble opplevd på den måten pasienten gir uttrykk for. For leger generelt, og særlig for leger som tar på seg oppgaver som sakkyndig, er saken en viktig påminnelse om betydningen av å avklare legens rolle og hensikten og rammen for konsultasjon med pasienten for å unngå misforståelser.

Oppgitte interessekonflikter: Ingen

Manuskriptet ble mottatt 9.11. 2009 og godkjent 10.12. 2009. Medisinsk redaktør Petter Gjersvik. 